\title{
Food consumption and nutrient intake in day care and at home in 3-year-old Finnish children
}

\author{
Jenni Lehtisalo ${ }^{1, *}$, Maijaliisa Erkkola ${ }^{1,2}$, Heli Tapanainen ${ }^{1}$, Carina Kronberg-Kippilä ${ }^{1}$, \\ Riitta Veijola ${ }^{3}$, Mikael Knip ${ }^{4,5}$ and Suvi M Virtanen ${ }^{1,5,6}$ \\ 'Department of Lifestyle and Participation, Nutrition Unit, National Institute for Health and Welfare, PO Box 30, \\ $\mathrm{FI}-00271$, Helsinki, Finland: ${ }^{2}$ Division of Nutrition, Department of Food and Environmental Sciences, \\ University of Helsinki, Helsinki, Finland: ${ }^{3}$ Department of Paediatrics, University of Oulu, Oulu, Finland: \\ ${ }^{4}$ Hospital for Children and Adolescents and Folkhälsan Research Institute, University of Helsinki, Helsinki, \\ Finland: ${ }^{5}$ Department of Paediatrics and Research Unit, Tampere University Hospital, Tampere, Finland: \\ ${ }^{6}$ Tampere School of Public Health, University of Tampere, Tampere, Finland
}

\section{Submitted 20 July 2009: Accepted 15 March 2010}

\begin{abstract}
Objective: To assess and compare the food consumption and nutrient intake between 3-year-old children cared for at home full-time and those attending day care outside the home. Nutrient intake on weekdays and weekends was also studied.

Design: Cross-sectional sample of children invited to the nutrition study within the Type 1 Diabetes Prediction and Prevention (DIPP) birth cohort born in 2001. Families returned 3-d food record completed close to the child's third birthday. Subjects: A total of 471 pre-school children aged 3 years of whom 285 had only been cared for at home during the recording time and 186 had attended day care outside the home.

Results: Among the children cared for outside the home, there were more consumers of recommendable foods as fresh vegetables, fruits, berries, rye bread, fish, skimmed milk and vegetable margarines, than among those cared for at home. The day-care group had higher intake of protein, dietary fibre, thiamine, potassium and magnesium, and lower intake of sucrose compared with the group cared for at home. Adjustment for sociodemographic factors did not change the results. In all children, food consumption was more varied on weekdays compared with weekends. On weekdays, children had higher intake of dietary fibre and protein and lower intake of sucrose compared to weekends.

Conclusions: The type of day care was associated with food consumption and nutrient intake among pre-school children and hence might have an impact on their nutrition and health. The diet of the children attending day care outside the home was more balanced and closer to the national recommendations.
\end{abstract}

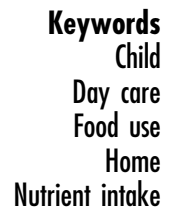

Children establish eating behaviour in early life and eating environment is important in shaping their food preferences $^{(1)}$. The basis for dietary habits is built in everyday situations at home and in day care, when food is selected and prepared and meals are served. Accordingly, day care and day-care personnel share with parents the responsibility for a child's nutrition. In Finland approximately half of the children aged 0-6 years, 50\% in 2004 ${ }^{(2)}$, are enrolled in the municipal day-care system. Of these children, $70 \%$ are cared for in an institutional day-care centre and $30 \%$ in family day care, which typically takes place in the care giver's home with only a few other children. According to the Finnish recommendation ${ }^{(3)}$ meals eaten in day care should cover two-thirds of a child's daily energy intake.
There is limited data available on children's food habits and nutrition in day care outside the home. Most studies have only reported consumption of selected foods ${ }^{(4,5)}$ or evaluated the menus of the child-care centres ${ }^{(6,7)}$. Previous data on nutrient intakes suggest that energy intake in day care is lower than recommended ${ }^{(8,9)}$ although this might be compensated for by the meals taken at home ${ }^{(9)}$. When single meals were compared, the intake of several vitamins at lunch was higher in day care than at home ${ }^{(10)}$. Micronutrient intake over the whole day was also shown to be greater in the group of children spending all day at pre-school compared with the half-day group ${ }^{(8)}$. To our knowledge, there are no previous studies comparing food consumption or nutrient intake between children cared for full time at home and those attending day care outside the home. 
The aim of the present study is to assess children's food consumption and nutrient intake at home and in day care outside the home. The primary interest is the differences between the children cared for at home and those attending day care outside the home. Differences in food consumption and nutrient intake between weekdays and weekends are also examined.

\section{Subjects and methods}

\section{Subjects}

The subjects in the present study are participants of the Type 1 Diabetes Prediction and Prevention Study (DIPP)-cohort (http://www.dipp.fi/e_index.htm) ${ }^{(11)}$. In study hospitals, all families with newborn babies were invited to participate in screening of genetic susceptibility for type 1 diabetes and written informed consent was requested from the parents. Babies carrying high-risk or moderate-risk human leukocyte antigen (HLA) class II genotypes ( $15 \%$ of all) were recruited for the study and observed for diet, growth, viral infections and type 1 diabetes-associated autoantibodies at 3-month to 12-month intervals. The study was approved by the ethics committee of the participating hospitals. The present study cohort includes the at-risk children born in 2001 in Tampere and Oulu University Hospitals ( $n$ 836). Both hospitals operate on a wider area; the Oulu area covers forty-two municipalities in Northern Finland and the Tampere area thirtyfour municipalities in Southern Finland, including urban and rural areas.

The present study comprises all children whose families returned the 3-year structured dietary questionnaire with the 3-d food record attached ( $n$ 484, 58\% of the children recruited in 2001). The children for whom food consumption had been recorded only for $2 \mathrm{~d}$ ( $n 20 ; 4 \%$ ) or $1 \mathrm{~d}(n 7 ; 1 \%)$ were included. Altogether $13(3 \%)$ food records were excluded due to inadequate information giving a total of 471 (57\% of those recruited) children with acceptable dietary data. Data on parental education and number of siblings were obtained from a questionnaire completed at 3 months after the baby's birth.

Among the participants, there were three different types of day care: 285 (60\%) had only been eating and cared for at home by parents or relatives during the recording period, 136 (29\%) had attended an institutional day-care centre and 50 (11\%) had attended small-sized family day care. In the analysis, the two latter groups were combined giving one group of children cared for exclusively at home in addition to another group also cared for at day care outside the home. As it is not possible to determine the duration of day-care time for children at home, all foods eaten during the day $(24 \mathrm{~h})$ were included in the analysis in comparing the groups. For day-care children, the meals eaten both at home and at day care were included.

\section{Dietary data}

Data on each child's diet were obtained from a questionnaire and a 3 -d food record completed close to the child's third birthday. The 3 -d food record consisted of consecutive days, two weekdays and one weekend day (Thursday-Saturday or Sunday-Tuesday). A separate food record was given to day-care personnel if the child was attending day care outside the home during the recording days. The families and day-care personnel were given written instructions to record with household measures all the foods the child had eaten and all vitamin and mineral supplements given to the child. They were also asked to record the type, brand and preparation method of foods. Trained study nurses checked the questionnaire and food records during respective visits and missing data were added after discussion, when needed. Thereafter, the study nutritionists checked the food records and confirmed the data by phone if necessary.

Dietary data were typed and analysed using a software program developed at the National Public Health Institute and the food composition database Fineli ${ }^{(12)}$ (http:// www.fineli.fi, for more detailed description, see articles Kyttälä et al. and Reinivuo et al. in this issue). The program allows modification of standard recipes and personal recipes were used whenever possible.

For food consumption, foods and beverages were categorised and summarised and the proportion of consumers was calculated for each food and food group. To be considered as a consumer a child must have consumed a certain food at least once during the recording period. Amount consumed was calculated as a median of food records because the data did not meet the assumptions for normal distribution. For nutrient intake, an estimate of the average daily intake was calculated by means of food records and intakes from both foods and supplements were included. Proportions of consumers and means of food and nutrient intake were assessed separately for weekdays and weekends.

\section{Statistical analyses}

Nutrient intake on weekdays and weekends were compared using the paired-samples $t$ test. In those analyses all children were handled as one group. None of the children were cared for outside the home during weekends and therefore all analyses by the type of day care were based on dietary data from weekdays only. Proportions of consumers and non-consumers for food consumption were analysed using the Fisher's exact test and differences in food amounts consumed with the Mann-Whitney $U$ test. Nutrient intakes were analysed using the $t$ test for independent samples. A logistic regression analysis was applied to study food consumption and nutrient intake in relation to selected sociodemographic variables. The endpoints were determined as consumption $v$. no consumption of food during the recording period and belonging to the highest terter of energy-adjusted intake 
$v$. belonging to the other terters. Parental education and number of siblings were included in the final multivariate analyses as confounding variables based on evidence from the literature and, accordingly, associations observed in the present study. Associations between the type of day care and sociodemographic variables were also tested using the $\chi^{2}$ test. Adjustment for energy intake was calculated as proportion of energy (E\%) for energy nutrients and nutrient intake per $1 \mathrm{MJ}$ of energy for vitamins and minerals. The statistical packages for the social sciences statistical software package version 14 for Windows (SPSS Inc., Chicago, IL, USA) was used for the statistical analyses.

\section{Results}

The characteristics of the participants according to the type of day care are presented in Table 1. Altogether seventy-five children (16\%) followed a special diet having at least one allergy or other diet restriction (data not shown). The children born in Northern Finland and the ones having two or more siblings were more commonly cared for at home (Table 1). There was no sex difference in relation to the type of day care. Boys did, however, have a higher intake of energy $(5 \cdot 35 \mathrm{MJ} v .5 \cdot 07 \mathrm{MJ}$, $P=0 \cdot 002)$ compared with girls and hence higher intake of several nutrients also. Differences were not significant when adjusted for energy and, consequently, nutrient intakes are presented and analysed as energy-adjusted values combining boys and girls.
Food consumption and nutrient intake in relation to the type of day care

Only weekdays were included when comparing the diets by the type of day care. Of the children cared for at home ten ( $4 \%$ ) had only recorded weekend days and were excluded from the analysis. Altogether 1379 recorded days were eligible for the analysis, of which 920 were weekdays, giving an average of 1.91 weekdays for the children cared for at home and 2.03 for those attending day care (difference not significant).

Overall, the children attending day care outside home consumed higher amounts of foods compared with those cared for at home, whereas the proportions of consumers were similar for most of the main food groups (Table 2). Among the children attending day care outside the home, there was a higher proportion of consumers of fresh vegetables and salads, fresh fruit, bread, porridge, savoury baked goods, milk, fish dishes and vegetable fat than among the ones cared for at home. Among the children cared for at home, there were more consumers of soft drinks and sweet baked goods.

Energy intake on weekdays was similar in the day-care group and in the group cared for at home, but sources of energy varied according to the type of day care (Table 3 ). The proportion of energy from protein was higher in the group cared for outside home, whereas the proportion of energy from sucrose was lower. Children cared for outside home also had a higher intake of dietary fibre, both with and without energy adjustment.

Vitamin and mineral intakes are presented as energyadjusted values (Table 4). When not adjusted for energy,

Table 1 Characteristics of the children $(n 471)$ cared for at home $(n 285,60 \%)$ and in day care outside home $(n 186,40 \%)$

\begin{tabular}{|c|c|c|c|c|c|}
\hline \multirow[b]{2}{*}{ Characteristics $(n)$} & \multicolumn{2}{|c|}{ Cared for at home } & \multicolumn{2}{|c|}{ In day care outside the home } & \multirow[b]{2}{*}{$P$ value* } \\
\hline & $n$ & $\%$ & $n$ & $\%$ & \\
\hline Sex & & & & & $0 \cdot 163$ \\
\hline Girls (237) & 136 & 48 & 101 & 54 & \\
\hline Boys (243) & 149 & 52 & 85 & 46 & \\
\hline Region & & & & & $0 \cdot 013$ \\
\hline Northern Finland (174) & 118 & 41 & 56 & 30 & \\
\hline Southern Finland (297) & 167 & 59 & 130 & 70 & \\
\hline Maternal education* & & & & & $0 \cdot 371$ \\
\hline No vocational education (35) & 21 & 7 & 14 & 8 & \\
\hline Vocational school or course (134) & 79 & 28 & 55 & 29 & \\
\hline Upper secondary vocational education (179) & 118 & 41 & 61 & 33 & \\
\hline Academic education (112) & 63 & 22 & 49 & 26 & \\
\hline Missing information (11) & 4 & 2 & 7 & 4 & \\
\hline Paternal education* & & & & & 0.602 \\
\hline No vocational education (20) & 12 & 4 & 8 & 4 & \\
\hline Vocational school or course (176) & 113 & 39 & 63 & 34 & \\
\hline Upper secondary vocational education (154) & 96 & 34 & 58 & 31 & \\
\hline Academic education (105) & 59 & 21 & 46 & 25 & \\
\hline Missing information (16) & 5 & 2 & 11 & 6 & \\
\hline Number of siblingst & & & & & $<0.001$ \\
\hline None (217) & 126 & 44 & 91 & 49 & \\
\hline One (145) & 78 & 27 & 67 & 36 & \\
\hline Two or more (94) & 76 & 27 & 18 & 10 & \\
\hline Missing information (15) & 5 & 2 & 10 & 5 & \\
\hline
\end{tabular}

${ }^{*}$ Pearson $\chi^{2}$.

tAt the time of birth of the child. 
Table 2 Consumption of food groups and selected foods as median daily consumption and proportion of consumers on weekdays in children aged 3 years cared for at home $(n 275)$ and in day care outside home $(n 186)$

\begin{tabular}{|c|c|c|c|c|c|c|}
\hline \multirow[b]{2}{*}{ Food group } & \multicolumn{2}{|c|}{ Proportion of consumers (\%) } & \multirow[b]{2}{*}{$P$ value* } & \multicolumn{2}{|c|}{ Median amount consumed (all children, $g / d$ ) } & \multirow[b]{2}{*}{$P$ valuet } \\
\hline & $\begin{array}{l}\text { Cared for } \\
\text { at home }\end{array}$ & $\begin{array}{l}\text { In day care outside } \\
\text { the home }\end{array}$ & & $\begin{array}{l}\text { Cared for } \\
\text { at home }\end{array}$ & $\begin{array}{l}\text { In day care outside } \\
\text { the home }\end{array}$ & \\
\hline Vegetables and vegetable dishes & 79 & 94 & $<0.001$ & 29 & 43 & 0.002 \\
\hline Fresh vegetables and salads & 63 & 88 & $<0.001$ & 15 & 21 & 0.001 \\
\hline Cooked vegetables & 11 & 15 & $0 \cdot 257$ & 0 & 0 & 0.362 \\
\hline Fruit and berries & 92 & 98 & $0 \cdot 127$ & 119 & 157 & 0.018 \\
\hline Fresh fruit & 70 & 79 & 0.024 & 40 & 34 & 0.692 \\
\hline Fresh berries & 16 & 12 & $0 \cdot 182$ & 0 & 0 & $0 \cdot 147$ \\
\hline Cereal products & 100 & 100 & $1 \cdot 000$ & 190 & 237 & 0.001 \\
\hline Rye bread & 59 & 83 & $<0.001$ & 7 & 13 & $<0.001$ \\
\hline Other bread & 78 & 92 & $<0.001$ & 20 & 29 & $<0.001$ \\
\hline Porridge & 71 & 87 & $<0.001$ & 107 & 159 & $<0.001$ \\
\hline Sweet baked goods & 70 & 55 & 0.001 & 15 & 4 & $<0.001$ \\
\hline Savoury baked goods & 31 & 45 & 0.004 & 0 & 0 & 0.024 \\
\hline Milk products & 99 & 97 & 0.495 & 465 & 509 & 0.005 \\
\hline Milk, skimmed & 46 & 64 & $<0.001$ & 0 & 100 & 0.001 \\
\hline Milk, fat $1-2 \%$ & 64 & 84 & $<0.001$ & 100 & 225 & 0.000 \\
\hline Soured milks & 63 & 67 & 0.488 & 75 & 64 & 0.382 \\
\hline Cheese & 63 & 68 & $0 \cdot 320$ & 5 & 5 & 0.753 \\
\hline Meat dishes & 97 & 99 & $0 \cdot 328$ & 133 & 160 & 0.006 \\
\hline Meat dishes & 86 & 92 & 0.055 & 100 & 114 & 0.032 \\
\hline Sausage dishes & 63 & 73 & 0.033 & 6 & 11 & 0.055 \\
\hline Fish dishes & 31 & 41 & 0.029 & 0 & 0 & 0.033 \\
\hline Side dishesł & 84 & 91 & 0.033 & 80 & 90 & 0.012 \\
\hline Fat spreads & 91 & 98 & 0.001 & 9 & 12 & $<0.001$ \\
\hline Vegetable margarine & 44 & 78 & $<0.001$ & 0 & 5 & $<0.001$ \\
\hline $\begin{array}{l}\text { Butter and butter spread (fat } \\
>60 \% \text { ) }\end{array}$ & 32 & 38 & 0.194 & 0 & 0 & $0 \cdot 188$ \\
\hline Beverages & 92 & 87 & $0 \cdot 112$ & 225 & 150 & 0.001 \\
\hline Juice drinks & 72 & 65 & $0 \cdot 124$ & 88 & 50 & $0 \cdot 153$ \\
\hline Soft drinks & 23 & 15 & 0.031 & 0 & 0 & 0.018 \\
\hline Added sugars and sweets & 78 & 77 & 0.910 & 5 & 4 & 0.251 \\
\hline Added sugar & 35 & 35 & $1 \cdot 000$ & 0 & 0 & 0.790 \\
\hline Chocolate and confectionery & 68 & 67 & $0 \cdot 840$ & 3 & 2 & 0.319 \\
\hline
\end{tabular}

${ }^{*}$ Fisher's exact test.

+Mann-Whitney $U$ test.

fe.g. potatoes, rice and pasta.

the children cared for outside the home had higher intakes of niacin, riboflavin, calcium, iron, zinc and selenium compared with those cared for at home (data not shown). As for the energy-adjusted intakes, higher intake in the group attending day care remained for thiamine, potassium and magnesium. There were no differences in favour of the group cared for at home.

\section{Food consumption and nutrient intake in relation to sociodemographic variables}

Food consumption was further analysed using a logistic regression model to examine relations with sociodemographic variables (Table 5). The type of day care was associated with the food consumption; attending day care outside home predicted being a consumer of vegetables, bread, porridge, milk, margarine, sausage dishes and side dishes compared with home care. Having a father with academic education predicted consumption of fresh vegetables, skimmed milk, rye bread and other bread compared with having a father with no vocational education. Having a mother with vocational education predicted consumption of sweet baked goods compared with having a mother with no vocational education. Maternal or paternal upper secondary vocational education was associated with consumption of skimmed milk compared with non-educated parents. Having two or more siblings predicted not consuming any fresh fruit compared with having no siblings ( $P$ for all $<0 \cdot 05$, data not shown).

Adjustment for sociodemographic factors did not change the results for nutrient intake and the type of day care, except for thiamine (data not shown). In a logistic regression model, attending day care outside home predicted having a high intake of protein $(\mathrm{OR}=1.769$, $P=0.007)$, dietary fibre $(\mathrm{OR}=1.578, P=0.036)$, potassium $(\mathrm{OR}=1.670, \quad P=0.017)$ and magnesium $(\mathrm{OR}=$ $1 \cdot 679, P=0 \cdot 015)$. Day care outside the home was also associated with lower intake of sucrose $(\mathrm{OR}=0.594$, $P=0 \cdot 019)$. In terms of the other background variables, maternal education was not associated with nutrient intake. Having a father with academic education predicted a higher proportion of energy from protein and a higher energy-adjusted intake of dietary fibre compared with having a father with no vocational education. 
Table 3 Mean intake of energy and macronutrients on weekdays in children aged 3 years cared for at home $(n 275)$ and in day care outside the home $(n 186)$

\begin{tabular}{|c|c|c|c|c|c|c|}
\hline & \multicolumn{2}{|c|}{ Cared for at home } & \multicolumn{2}{|c|}{ In day care outside the home } & \multirow[b]{2}{*}{$P$ value* } & \multirow[b]{2}{*}{ Recommendationt } \\
\hline & Mean & SD & Mean & SD & & \\
\hline Energy (MJ) & $5 \cdot 1$ & $1 \cdot 1$ & $5 \cdot 3$ & $1 \cdot 0$ & 0.057 & $4 \cdot 9 / 5 \cdot 5 \ddagger$ \\
\hline Protein (g) & 46 & 12 & 50 & 13 & 0.001 & \\
\hline Protein (E\%) & $15 \cdot 6$ & $3 \cdot 1$ & $16 \cdot 1$ & $2 \cdot 5$ & 0.049 & 15 \\
\hline Carbohydrate (g) & 159 & 38 & 166 & 35 & 0.071 & \\
\hline Carbohydrate (E\%) & $53 \cdot 3$ & $7 \cdot 0$ & $53 \cdot 3$ & $5 \cdot 8$ & $0 \cdot 912$ & 55 \\
\hline Sucrose $(E \%)$ & $13 \cdot 4$ & $5 \cdot 7$ & $11 \cdot 6$ & $4 \cdot 6$ & $<0.001$ & $10 \S$ \\
\hline Fibre $(\mathrm{g})$ & $9 \cdot 3$ & $3 \cdot 4$ & 10 & $2 \cdot 9$ & $<0.001$ & \\
\hline Fat $(\mathrm{g})$ & 42 & 14 & 43 & 12 & 0.648 & \\
\hline Fat (E\%) & $30 \cdot 4$ & $6 \cdot 6$ & $29 \cdot 9$ & $5 \cdot 1$ & $0 \cdot 296$ & 30 \\
\hline Saturated fatty acids (SFA) (E\%) & $12 \cdot 6$ & $3 \cdot 4$ & $12 \cdot 2$ & $2 \cdot 9$ & $0 \cdot 284$ & $10 \|$ \\
\hline Monounsaturated fatty acids ( $\mathrm{E} \%$ ) & $9 \cdot 8$ & $2 \cdot 6$ & $9 \cdot 8$ & $2 \cdot 0$ & 0.989 & $10-15$ \\
\hline PUFA (E\%) & $3 \cdot 8$ & $1 \cdot 4$ & $3 \cdot 9$ & $1 \cdot 3$ & $0 \cdot 262$ & $5-10$ \\
\hline
\end{tabular}

$\mathrm{E} \%=$ proportion of daily energy.

${ }^{*} t$ test.

tFinnish Nutrition Recommendations, which are based on Nordic Nutrition Recommendations (Nordic council of Ministers, 2005).

$\ddagger$ Girls/boys.

$\S$ Sum of refined sugars added by manufacturers and consumers, approximately $10 \%$ of energy intake.

$\|$ SFA and trans fatty acid together, maximum $10 \%$ of energy intake.

Table 4 Intake of nutrients on weekdays in children aged 3 years cared for at home $(n 275)$ and in day care outside the home $(n$ 186), adjusted for energy (amount of nutrient/MJ of energy)

\begin{tabular}{|c|c|c|c|c|c|}
\hline \multirow[b]{2}{*}{ Nutrient (per MJ) } & \multicolumn{2}{|c|}{ Cared for at home* } & \multicolumn{2}{|c|}{ In day care outside the homet } & \multirow[b]{2}{*}{$P$ value } \\
\hline & Mean & SD & Mean & SD & \\
\hline Vitamin A (RE) & 148 & 159 & 147 & 149 & 0.928 \\
\hline Vitamin $E(\alpha-T E)$ & $1 \cdot 2$ & 0.59 & $1 \cdot 2$ & 0.48 & 0.541 \\
\hline Vitamin D $(\mu \mathrm{g})$ & $1 \cdot 4$ & $1 \cdot 0$ & $1 \cdot 4$ & $0 \cdot 88$ & $0 \cdot 531$ \\
\hline Vitamin C (mg) & 13 & $9 \cdot 5$ & 13 & $7 \cdot 1$ & 0.998 \\
\hline Folate $(\mu \mathrm{g})$ & 26 & $11 \cdot 6$ & 26 & $8 \cdot 7$ & $0 \cdot 762$ \\
\hline Niacin (NE) & $3 \cdot 4$ & $1 \cdot 2$ & 3.5 & 0.92 & 0.541 \\
\hline Pyridoxine (mg) & $0 \cdot 27$ & $0 \cdot 14$ & $0 \cdot 28$ & $0 \cdot 12$ & 0.585 \\
\hline Riboflavin (mg) & $0 \cdot 31$ & $0 \cdot 12$ & 0.33 & $0 \cdot 11$ & 0.053 \\
\hline Thiamine (mg) & $0 \cdot 17$ & 0.09 & $0 \cdot 19$ & 0.09 & 0.041 \\
\hline Calcium (mg) & 179 & 59 & 184 & 46 & 0.335 \\
\hline Iron (mg) & $1 \cdot 3$ & 0.49 & $1 \cdot 4$ & 0.92 & $0 \cdot 120$ \\
\hline Potassium (mg) & 438 & 104 & 477 & 104 & $<0.001$ \\
\hline Magnesium (mg) & 39 & $8 \cdot 1$ & $41 \cdot 2$ & $6 \cdot 6$ & $<0.001$ \\
\hline Selenium $(\mu \mathrm{g})$ & $6 \cdot 7$ & $1 \cdot 76$ & $6 \cdot 8$ & 1.54 & 0.582 \\
\hline Zinc (mg) & $1 \cdot 40$ & 0.37 & 1.45 & $0 \cdot 34$ & $0 \cdot 177$ \\
\hline
\end{tabular}

RE, retinol equivalent; $\alpha-T E$, alphatocopherol equivalent; NE, niacin equivalent.

${ }^{*}$ Daily energy intake $5 \cdot 10 \mathrm{MJ} / \mathrm{d}$.

tDaily energy intake $5 \cdot 30 \mathrm{MJ} / \mathrm{d}$.

$\ddagger t$ test.

Having two or more siblings was associated with having a higher intake of iron and a lower intake of vitamin D and having one sibling with a higher intake of fibre, all compared with having no siblings. Having siblings predicted a higher intake of thiamine ( $P$ for all $<0 \cdot 05$, data not shown) compared with having no siblings.

\section{Nutrient intake on weekdays and weekends}

Daily energy intake was similar on weekdays and weekends, but macro- and micronutrient intakes varied according to the type of the day (Table 6). Altogether 413 children had both weekdays and weekends recorded and were eligible for the analysis. On weekdays, the energy-adjusted intakes of protein and dietary fibre were higher, while the intake of sucrose was higher on weekends. Diet on weekends was similar for all children regardless of the type of day care.

\section{Discussion}

In the present study of 3-year-old Finnish children, the quality of diet and intake of nutrients varied with the type of day care. The children attending day care outside the home consumed more food and a wider variety of different foods compared with the children cared for at home. Being cared for outside the home on weekdays seems to improve the quality of diet. The children cared 
Table 5 OR for consumption of selected foods and food groups during weekdays in relation to the type of day care in children aged 3 years: a logistic regression model ${ }^{\star}$

\begin{tabular}{|c|c|c|c|}
\hline \multirow[b]{2}{*}{ Consumer of } & \multicolumn{2}{|c|}{ Day care type: in day care outside the home $v$. cared for at home } & \multirow[b]{2}{*}{$P$ value } \\
\hline & OR & $95 \% \mathrm{Cl}$ & \\
\hline Fresh vegetables and salads & $3 \cdot 79$ & $2 \cdot 23,6 \cdot 42$ & $<0.001$ \\
\hline Cooked vegetables & $1 \cdot 38$ & $0 \cdot 77,2 \cdot 48$ & 0.274 \\
\hline Fresh fruit & $1 \cdot 50$ & $0.95,2.39$ & 0.085 \\
\hline Fresh berries & 0.63 & $0 \cdot 36,1 \cdot 12$ & $0 \cdot 115$ \\
\hline Rye bread & $3 \cdot 14$ & $1.95,5 \cdot 06$ & $<0.001$ \\
\hline Other bread & $3 \cdot 39$ & $1 \cdot 79,6 \cdot 39$ & $<0.001$ \\
\hline Porridge & $2 \cdot 38$ & $1 \cdot 42,3.99$ & 0.001 \\
\hline Sweet baked goods & 0.52 & $0.35,0.80$ & 0.002 \\
\hline Savoury baked goods & $1 \cdot 58$ & $1 \cdot 03,2 \cdot 35$ & 0.035 \\
\hline Milk, skimmed & $2 \cdot 11$ & $1 \cdot 40,3 \cdot 20$ & $<0.001$ \\
\hline Milk, fat $1-2 \%$ & $3 \cdot 08$ & $1 \cdot 88,5 \cdot 05$ & $<0.001$ \\
\hline Soured milks & 0.97 & $0.64,1.48$ & 0.895 \\
\hline Cheese & $1 \cdot 49$ & $0 \cdot 97,2 \cdot 27$ & 0.068 \\
\hline Meat dishes & $2 \cdot 07$ & $1 \cdot 05,4 \cdot 10$ & 0.037 \\
\hline Sausage dishes & 1.57 & $1 \cdot 02,2 \cdot 43$ & 0.042 \\
\hline Fish dishes & $1 \cdot 47$ & $0.97,2 \cdot 23$ & 0.072 \\
\hline Side dishest & $2 \cdot 53$ & $1 \cdot 29,4 \cdot 96$ & 0.007 \\
\hline Margarine & $4 \cdot 99$ & $3 \cdot 17,7 \cdot 85$ & $<0.001$ \\
\hline Butter and butter spread (fat $>60 \%$ ) & $1 \cdot 14$ & $0 \cdot 75,1 \cdot 73$ & 0.536 \\
\hline Juice drinks & $0 \cdot 77$ & $0 \cdot 50,1 \cdot 18$ & 0.226 \\
\hline Soft drinks & 0.63 & $0.37,1 \cdot 07$ & 0.087 \\
\hline Added sugar & $1 \cdot 28$ & $0.84,1.94$ & 0.252 \\
\hline Chocolate and confectionery & $0 \cdot 84$ & $0.55,1 \cdot 28$ & 0.410 \\
\hline
\end{tabular}

*Adjusted for maternal and paternal vocational education and number of siblings.

te.g. potatoes, rice and pasta.

Table 6 Mean intake of energy and macro-nutrients on weekdays and weekends in children aged 3 years (all children, $n$ 413)

\begin{tabular}{|c|c|c|c|c|c|}
\hline & \multicolumn{2}{|c|}{ Weekdays } & \multicolumn{2}{|c|}{ Weekends } & \multirow[b]{2}{*}{$P$ value* } \\
\hline & Mean & SD & Mean & SD & \\
\hline Energy (MJ) & $5 \cdot 15$ & $1 \cdot 1$ & $5 \cdot 17$ & $1 \cdot 3$ & 0.071 \\
\hline Protein $(\mathrm{g})$ & 48 & 13 & 45 & 15 & 0.001 \\
\hline Protein (E\%) & $15 \cdot 8$ & $3 \cdot 0$ & $15 \cdot 1$ & 3.9 & $<0.001$ \\
\hline Carbohydrate (g) & 161 & 37 & 162 & 45 & 0.679 \\
\hline Carbohydrate (E\%) & $53 \cdot 4$ & $6 \cdot 6$ & $53 \cdot 7$ & $8 \cdot 5$ & 0.619 \\
\hline Sucrose (E\%) & $12 \cdot 8$ & $5 \cdot 4$ & $14 \cdot 7$ & $6 \cdot 7$ & $<0.001$ \\
\hline Dietary fibre $(\mathrm{g})$ & $9 \cdot 7$ & $3 \cdot 3$ & $8 \cdot 4$ & $3 \cdot 4$ & $<0.001$ \\
\hline Fat $(\mathrm{g})$ & 42 & 14 & 44 & 17 & 0.098 \\
\hline Fat $(\mathrm{E} \%)$ & $30 \cdot 1$ & $6 \cdot 1$ & $30 \cdot 8$ & $7 \cdot 5$ & 0.071 \\
\hline Saturated fatty acids (E\%) & $12 \cdot 4$ & $3 \cdot 3$ & $12 \cdot 7$ & $3 \cdot 9$ & 0.128 \\
\hline Monounsaturated fatty acids ( $\mathrm{E} \%$ ) & $9 \cdot 8$ & $2 \cdot 4$ & $9 \cdot 9$ & $2 \cdot 9$ & 0.277 \\
\hline PUFA (E\%) & $3 \cdot 8$ & $1 \cdot 3$ & $3 \cdot 8$ & $1 \cdot 5$ & $0 \cdot 896$ \\
\hline
\end{tabular}

$E \%$, proportion of daily energy.

${ }^{\star}$ Paired $t$ test.

for outside the home more often consumed recommendable foods such as fresh vegetables, fruit, berries, rye bread, fish, skimmed milk and vegetable margarines, than did the children cared for at home. The day-care group had a higher intake of protein, dietary fibre, thiamine, potassium and magnesium, and a lower intake of sucrose compared with the group cared for at home. Associations between the type of day care and food consumption or nutrient intakes remained after adjustment for parental education and number of siblings. In all children, intake of dietary fibre and protein was higher and intake of sucrose was lower on weekdays compared with weekends.
There have been only two previous studies on the diet of children attending day care in Finland ${ }^{(13,14)}$. In both those studies, energy intake during day care as a proportion of total daily energy intake did not meet the Finnish recommendation, i.e. two-thirds of the total daily energy intake ${ }^{(3)}$. That was, however, compensated for by the meals consumed at home. The same was observed in a Swedish study ${ }^{(9)}$. Energy intake during day care as a proportion of total daily energy intake was not examined in the present study, since some children were only attending day care for half the day. On average, in the present study, nutrient intake was relatively close to the 
Nordic recommendations ${ }^{(15)}$. The proportions of energy from fat, protein and carbohydrates were in accordance with the nutritional recommendations, but the proportion of energy from saturated fat was higher while that from polyunsaturated fats was lower than recommended. In all children, the intake of energy was at the same level as in previous Finnish studies among 3-year-olds ${ }^{(16,17)}$. Intake of sucrose in the present study was higher than in another study from the beginning of the $1990 \mathrm{~s}^{(16)}$.

To our knowledge, no previous studies have compared food consumption and nutrient intake between children cared for at home and children cared for outside the home. However, Garemo et al. ${ }^{(18)}$ have reported children spending more time at day care having higher intakes of energy, protein and fat and a lower intake of sucrose. Other previous studies in day-care centres have mainly focused on monitoring and evaluating nutritional goals and recommendations for day-care meals ${ }^{(4,5,8,9,13)}$. The quality of school meals and packed lunches differed in British primary schools ${ }^{(19)}$. Even though British school lunches and Finnish day-care meals are not fully comparable, there were interesting similarities, e.g. higher intake of potassium in the children eating school lunches, and higher intake of sugar among children eating packed lunches from home.

It is noteworthy that children attending day care outside the home consumed more food but did not have a higher intake of energy. That implies their diet was not as dense with energy as that of the children cared for at home. These results also indicate that the children cared for outside home had a diet with higher nutrient density; when calculated per MJ of energy, they had higher intakes of protein, dietary fibre, thiamine, magnesium and potassium compared with the children cared for at home. Bollella et $a l^{(8)}$ discovered that children attending preschool all-day had higher intakes of calcium and vitamins $\mathrm{A}, \mathrm{E}$ and $\mathrm{B}_{12}$ compared with children attending preschool for only half the day, even when intakes at home were taken into account. That suggests that meals consumed at day care have a higher nutrient density than meals consumed at home.

Although the observed differences in food consumption did not lead to such substantial differences in nutrient intake, they might still be of importance. Children's food preferences are shaped via early experiences of food and eating $^{(1)}$ and food preferences established in childhood persist into adulthood ${ }^{(20)}$. At day care, children seem to be offered a greater variety of foods leading to a more diverse diet that can have a long-term impact on their health. It is also noteworthy that the intake of sucrose was lower in the children cared for outside the home. Frequent consumption of snacks appear to be associated with higher sucrose intake ${ }^{(21)}$, and a snack-dominating meal pattern might be more frequent among children cared for at home, whereas eating occasions are more regulated in day care. We have earlier shown that a high intake of sucrose is associated with poor nutritional quality in children ${ }^{(22)}$.

There are certain limitations to the present study. The dietary assessment method employed was an unweighed food record. In general, however, food records are considered a reliable method for estimating the food intake in young children ${ }^{(23)}$ and unweighed records have performed well when compared with weighed records ${ }^{(24)}$. It has also been shown that parents are generally accurate reporters of their child's diet ${ }^{(25)}$ but, to our knowledge, there are no validation studies of other surrogate reporters for children. Livingstone and Robson ${ }^{(26)}$ suggest that other care takers of children might have varying levels of motivation and interest. Ball et al. ${ }^{(5)}$ used the structured observation method for estimating dietary intake in day care. Observation, however, usually limits the amount of day-care centres in the study and the results cannot be generalised. In this study, we were able to collect information from more than 100 different locations.

Determining the day-care time for the children cared for at home was considered not plausible and all meals eaten during the day were included when comparing the types of day care. Hence analysing the quality of the meals served in day care was not possible and food served at home may have contributed to healthier food consumption and nutrient intake among the day-care group. However, there were no differences between the groups during the weekends when all children were only eating at home.

Although the recording period was $3 \mathrm{~d}$, not all days were eligible for the analysis by type of day care. None of the children attended day care on weekends, and hence only weekdays were included in the comparison of the types of day care. Consequently, for most of the participants, only $2 \mathrm{~d}$ were included when calculating the means, which made the actual recording period rather short. However, only group comparisons were used in the analysis and there was no ranking of the participants.

We did not exclude potential under-reporters from the analysis. During childhood, diet tends to be highly variable from day to day and the identification of underreporters is difficult. In a similar Swedish study underreporting was controlled by calculating energy intake/ basal metabolic rate ratio but none of the children were actually excluded because of a low value ${ }^{(9)}$. Underreporting seems not to be very common in this population; energy intake of the girls was above the Finnish recommendation and that of the boys met the recommendation. Ideally, we would have included anthropometric data to have something against which to check the reliability of reporting. However, data on children's weight and height were not available at the time.

Subjects in this study carry increased HLA-conferred susceptibility for type 1 diabetes, but they are expected to be representative of young Finnish children in terms of food consumption. Almost $20 \%$ of the Finnish population 
have HLA-defined predisposition to type 1 diabetes, whereas only $3-4 \%$ of those actually progress to clinical disease. The food consumption and nutrient intake of the participants was comparable with the Finnish children in previous studies ${ }^{(16,17)}$. The influence of the cohort setting on these results must also be taken into consideration, although that effect most likely reduces the observed differences. Day-care meals are similar for all children but parents are responsible for meals at home and therefore food consumption at home would probably be more affected by potential drop out of less educated or less interested parents.

In conclusion, the diet of children in day care outside the family home was more balanced and closer to the recommendations than the diet of children cared for in the family home, with respect to e.g. sucrose, fibre and some vitamins and minerals. Attention should be paid to the promotion of healthy eating habits in children cared for at home full time. The present findings also emphasise the importance of taking dietary intake in day care into account in nutritional studies among children. Food preferences in early life may help predict later preferences and acquiring a healthy and balanced diet during childhood may contribute to prevention of chronic diseases.

\section{References}

1. Birch LL (1998) Psychological Influences on the Childhood Diet. J Nutr 128, Suppl. 2, 407S-410S.

2. Nordic Social Statistical Committee NOSOSCO (2007) Social Protection in Nordic Countries 2005. Copenhagen: AN: sats.

3. Hasunen K, Kalavainen M, Keinonen H et al. (2004) Lapsi, Perhe ja Ruoka. Imeväis - ja Leikki-ikäisten Lasten, Odottavien ja Imettävien Äitien Ravitsemussuositus (In Finnish, Summary in English: The Child, Family and Food. Nutrition Recommendations for Infants and Young Children as well as Pregnant and Breastfeeding Mothers). Publications of the Ministry of Social Affairs and Health 2004:11. Helsinki: Edita Prima Oy; available at http://www.stm.fi/c/ document_library/get_file?folderId $=28707$ \&name $=$ DLFE3555.pdf\&title=Lapsi_perhe_ja_ruoka_fi.pdf

4. Padget A \& Briley ME (2005) Dietary intakes at child-care centers in central Texas fail to meet food guide pyramid recommendations. J Am Diet Assoc 105, 790-793.

5. Ball SC, Benjamin SE \& Ward DS (2008) Dietary intakes in North Carolina child-care centers: are children meeting current recommendations? J Am Diet Assoc 108, 718-721.

6. Oakley CB, Bomba AK, Knight KB et al. (1995) Evaluation of menus planned in Mississippi child-care centers participating in the Child and Adult Care Food Program. J Am Diet Assoc 95, 765-768.

7. Fleischhacker S, Cason KL \& Achterberg C (2006) "You had peas today?": a pilot study comparing a Head Start childcare center's menu with the actual food served. $J$ Am Diet Assoc 106, 277-280.

8. Bollella MC, Spark A, Boccia LA et al. (1999) Nutrient intake of Head Start children: home vs. school. J Am Coll Nutr 18, 108-114.
9. Sepp H, Lennernäs M, Pettersson R et al. (2001) Children's nutrient intake at preschool and at home. Acta Paediatr 90, 483-491.

10. Ziegler P, Briefel R, Ponza M et al. (2006) Nutrient intakes and food patterns of toddlers' lunches and snacks: influence of location. J Am Diet Assoc 106, Suppl. 1, S124-S134.

11. Kupila A, Muona P, Simell T et al. (2001) Feasibility of genetic and immunological prediction of type I diabetes in a population-based birth cohort. Diabetologia 44, 290-297.

12. National Institute for Health and Welfare (2005) Fineli Finnish Food Composition Database. Release 5. http:// www.fineli.fi/

13. Partanen T, Ahonen S, Aminoff I et al. (1998) Päiväkotiikäisten Lasten Ravinnonsaanti Päiväkodissa ja Kotona (In Finnish, Title in English: Food Intake in Children of Day care Centre Age in Day care Centres and at Home). Publications of the City of Helsinki Environment Centre 9/98. Helsinki: City of Helsinki Environment Centre.

14. Åkerlund M (2003) 3-6-vuotiaiden Lasten Ruokailu Luonnonmukaisesti Sekä Tavanomaisesti Tuotettua Ruokaa Tarjoavassa Päiväkodissa ja Kotona (In Finnish, Masters' Thesis). Kuopio: University of Kuopio.

15. Nordic Council of Ministers (2005) Nordic Nutrition Recommendations: Integrating Nutrition and Physical Activity, 4th ed. Nord 2004:13. Arhus: Scanprint as.

16. Lagström H, Jokinen E, Seppänen R et al. (1997) Nutrient intakes by young children in a prospective randomized trial of a low-saturated fat, low-cholesterol diet. The STRIP Baby Project. Special Turku Coronary Risk Factor Intervention Project for Babies. Arch Pediatr Adolesc Med 151, 181-188.

17. Räsänen M, Kronberg-Kippilä C, Ahonen S et al. (2006) Intake of vitamin $\mathrm{D}$ by Finnish children aged 3 months to 3 years in relation to sociodemographic factors. Eur J Clin Nutr 60, 1317-1322.

18. Garemo M, Arvidsson Lenner R \& Strandvik B (2007) Swedish pre-school children eat too much junk food and sucrose. Acta Paediatrica 96, 266-272.

19. Rogers IS, Ness AR, Hebditch K et al. (2007) Quality of food eaten in English primary schools: school dinners vs packed lunches. Eur J Clin Nutr 61, 856-864.

20. Mikkilä V, Räsänen L, Raitakari OT et al. (2005) Consistent dietary patterns identified from childhood to adulthood: the cardiovascular risk in Young Finns Study. Br J Nutr 93, 923-931.

21. Ovaskainen ML, Reinivuo H, Tapanainen H et al. (2006) Snacks as an element of energy intake and food consumption. Eur J Clin Nutr 60, 494-501.

22. Erkkola M, Kronberg-Kippilä C, Kyttälä P et al. (2009) Sucrose in the diet of 3-year-old Finnish children: sources, determinants and impact on food and nutrient intake. Br J Nutr 101, 1209-1217.

23. Davies PS, Coward WA, Gregory J et al. (1994) Total energy expenditure and energy intake in the pre-school child: a comparison. Br J Nutr 72, 13-20.

24. Bingham SA, Gill C, Welch A et al. (1994) Comparison of dietary assessment methods in nutritional epidemiology: weighed records v. $24 \mathrm{~h}$ recalls, food-frequency questionnaires and estimated-diet records. Br J Nutr 72, 619-643.

25. Basch CE, Shea S, Arliss R et al. (1990) Validation of mothers' reports of dietary intake by four to seven year-old children. Am J Public Health 80, 1314-1317.

26. Livingstone MB \& Robson PJ (2000) Measurement of dietary intake in children. Proc Nutr Soc 59, 279-293. 